\title{
MODELLING OF GROUND BORNE VIBRATION INDUCED BY ROAD TRANSPORT
}

\author{
Tomas ASTRAUSKAS ${ }^{\mathbf{1}}$, Raimondas GRUBLIAUSKAS ${ }^{\mathbf{2}}$ \\ Vilnius Gediminas Technical University, Vilnius, Lithuania \\ E-mails: 'tomas.astrauskas@vgtu.lt; ${ }^{2}$ raimondas.grubliauskas@vgtu.lt
}

\begin{abstract}
Ground-borne vibrations induced by road transport is common source of environmental problem for residents living near roads where large flow of vehicles is. Any irregular unevenness of road surface increase the transport induced ground borne vibrations. The ground-borne vibrations travel through soil, different types of soil have different properties and transmission loss of vibrations is different. In this paper the spread of ground borne vibration is modelled using numerical modelling and represented using Surfer software. In this research is considered most common soil types in Lithuania: Peat, clay, sandy loam and loam. Calculated soil particle acceleration near vibration source was highest in Clay soil $\left(34,3 \mathrm{~mm} / \mathrm{s}^{2}\right)$. The calculations show that in peat soil vibration travel further than in other soils.
\end{abstract}

Keywords: transport, ground-borne vibration, numerical modelling, vibration map.

\section{Introduction}

Transportation is the means to carry people and goods from one place to another. This has become very important in each stage of human civilization. If the present means of transportation were not developed, situation of the world would be totally different. In today's world we use car every day. Ground traffic causes ground-borne vibrations. This impact could cause annoyance of residents who lives near streets or roads.

Random pavement surface irregularities exist on all pavements and are typically characterized by measures of pavement smoothness or roughness such as the International Roughness Index (IRI). Typically, random surface irregularities can result in randomly occurring dynamic forces that are up to 15 percent higher than the corresponding static forces. The impact of these dynamic forces on pavements results in randomly occurring groundborne vibration. Although random ground-borne vibration is always present (the pavement is never completely smooth and highway vehicles are never completely dynamically inert), it is too low to be perceived even by observers very close to the source (Hajek et al. 2006).

The propagation of traffic-induced vibration from the source depends on the distance from the receiver, frequency of vibration, topography between the source and the receiver, and on the soil and other geotechnical characteristics of the ground. Vibration propagates through the ground in the form of body waves (compression and shear waves), and in the form of surface or Rayleigh waves

The Rayleigh waves are the most important form for the propagation of traffic induced vibration because at the ground level the amplitude of the Rayleigh waves decreases (due to geometric spreading) as the inverse of the square root of the distance from the source, while the amplitude of body waves decrease as the inverse of the square of the distance from the source (Hajek et al. 2006; Athanasopoulos et al. 2000).

Like most vibration problems, traffic vibrations can be characterized by a source-path receiver scenario (Fig. 1). Vehicle contact with irregularities in the road surface (e.g., potholes, cracks and uneven manhole covers) induces dynamic loads on the pavement (Hunaidi 2000).

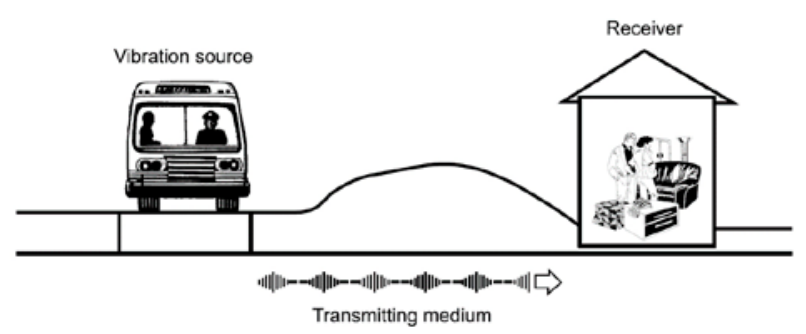

Fig. 1. Source path-receiver scenario (Hunaidi 2000) 
When a vehicle strikes an irregularity in the road surface, it generates an impact load and an oscillating load due to the subsequent "axle hop" of the vehicle. The impact load generates ground vibrations that are predominant at the natural vibration frequencies of the soil whereas the axle hop generates vibrations at the hop frequency (a characteristic of the vehicle's suspension system). If the natural frequencies of the soil coincide with any of the natural frequencies of the building structure or its components, resonance occurs and vibrations will be amplified (Hajek et al. 2006).

In this research mainly transmiting medium is considered. Loam is soil composed mostly of sand (particle size $>63 \mu \mathrm{m}$ ), silt (particle size $>2 \mu \mathrm{m}$ ), and a smaller amount of clay (particle size $<2 \mu \mathrm{m}$ ). Its composition is about $40-40-20 \%$ concentration of sand-silt-clay, respectively. These proportions can vary to a degree, however, and result in different types of loam soils: sandy loam, silty loam, clay loam, sandy clay loam, silty clay loam, and loam (Kaufmann, Cutler 2008). Sandy loam soil is when sand $1 / 3$ more amount in composition than other components (Ingels 2003).

In this research Banedanmark's new vibration model is used. Banedanmark's new vibration model is based on the fact that a source strength can be used to calculate vibration comfort estimates for buildings nearby a train alignment, provided a number of corrections to account for the effects of geology, distances between the track and the building as well as the properties of the buildings are applied. The principle scheme of model is shown in Fig. 2. This model is mainly used to calculate train induced ground borne vibration, but it is adapted for road transport (Banedanmark 2015).

The aim of this research to evaluate what soil of Lithuania has vibration higher transmission loss.

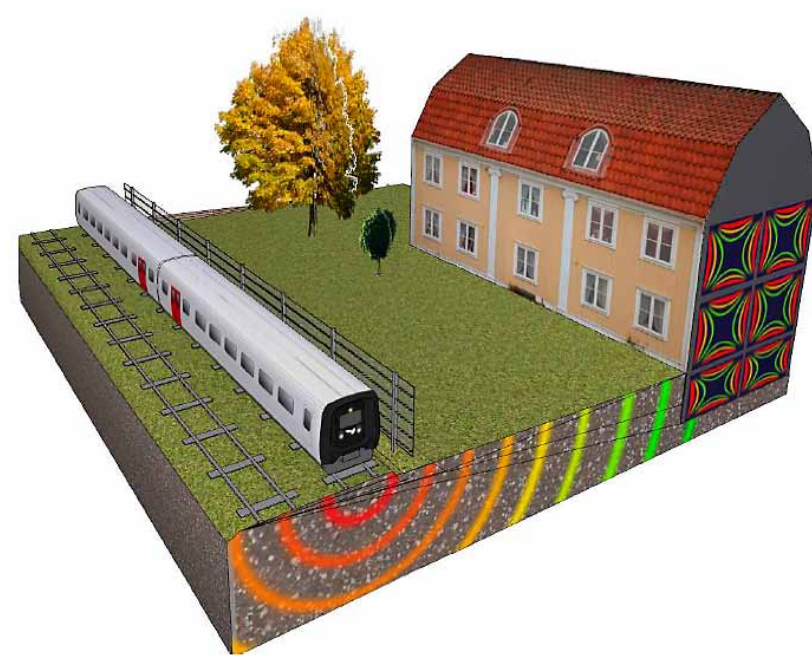

Fig. 2. Principle scheme of Banedanmark's vibration model (Banedanmark 2015)

\section{Method}

In this research Banedanmark's new vibration mod-el is adapted to evaluate the vibration transmission loss the different soils.

The numerical modelling used to evaluate the vibration waves attenuation in the different soils. For the result show is used Surfer software to represent map of vibration spread in different soils. In this research were chosen four soils that is typical in Lithuania which are clay, loam, sandy loam and peat.

Transmission of vibrations through a given type of soil consist of several components:

- Geometric spreading

- Viscous damping

Geometric spreading - Vibrations propagates as waves in the ground. The wave field will be plane within a vehicle length from track and at low frequencies, and will therefore not propagate as it moves away from the source. For higher frequencies the wavelength becomes shorter and the wave front more circular. Thus, a certain geometric spreading is expected since vibrations will propagate to a continuously wider area when moving away from the source.

In general, it can be expected that the wave front will propagate in line with following expression:

$$
a=a_{k}\left(\frac{r_{k}}{r}\right)^{m(f)} \text {. }
$$

Where $\mathrm{a}$ is the acceleration in a distance $\mathrm{r}$ from the source, and $a_{k}$ is the source strength (acceleration) in a distance $r_{k}(=7,5 \mathrm{~m})$. The exponent $\mathrm{m}(\mathrm{f})$ is expected to be frequency dependent, and in the most cases to be determined from tests.

For surface waves (Rayleigh waves) the value of $\mathrm{m}(\mathrm{f})$ is expected to be 0 at low frequencies and 1 at high frequencies.

In order to be capable of setting up a model for the progress of $\mathrm{m}(\mathrm{f})$ it is important to determine the frequency range where the wave field transforms from having plane to curved wave fronts. The transition of wave field type will not be very distinct, instead a more gradual effect is expected in the frequency range where the wavelengths are of same magnitude as the distance from track centre to source point, approx. 7,5 $\mathrm{m}$ (Banedanmark 2015). The following function for $\mathrm{m}(\mathrm{f})$ has the exact characteristic that it takes the value 0 at low frequencies and 1 at high frequencies:

$$
m(f) \approx 1-\exp \left(-\frac{f}{f_{b}}\right) .
$$

Where $f_{b}$ is the frequency where the wave field transforms from having plane to curved wave fronts. 
In order to apply the above expression for calculating the transmission loss it is necessary to determine $f_{b}=c / r_{k}$ which is a function of wave propagating velocity $c$ and the distance track centre to source point $r_{k}$. (Banedanmark 2015).

\section{Viscous damping}

The longer a distance a wave travels from source to recipient and the higher a frequency, the more wavelengths will occur between the source and recipient, and

therefore a greater frictional loss. The phenomenon can be described by a viscous damping model:

$$
a=a_{k} \cdot \exp \left(-\left(\frac{2 \pi f \eta}{c}\left|r-r_{k}\right|\right)\right) .
$$

Where $c$ is the propagating velocity of the wave, $\eta$ is the viscous damping constant for the current media the wave is traveling in, and $\left|r-r_{k}\right|$ is the distance from source to receiver point, $\mathrm{f}-$ frequency of calculation.

$$
c \approx 0,9 \sqrt{\left(\frac{E}{2 \rho(1+v)}\right)} .
$$

The equation No. 4 is the calculation of wave propagation velocity in the given media. The wave propagating velocity is a function of the physical characteristic of the ground, including E-modulus, density $\rho$, Poisson's ratio $v$ and the damping constant (Banedanmark 2015).

Table 1. Parameters of selected soils (Bolton, Wilson 1990; Gibson, Coyle 1968; Obrzud, Truty 2012; Kezdi 1974; Mott, Roland 2012)

\begin{tabular}{|l|l|l|l|l|l|}
\hline No. & $\begin{array}{c}\text { Name of } \\
\text { media }\end{array}$ & E- modulus & $\begin{array}{c}\text { Density } \rho \\
(\mathrm{kg} / \mathrm{m} 3)\end{array}$ & $\begin{array}{c}\text { Poisson } \\
\text { ratio v } \\
(-)\end{array}$ & $\begin{array}{c}\text { Viscous } \\
\text { damping } \\
\text { coeffient } \eta \\
(-)\end{array}$ \\
\hline 1. & Peat & $5,6 \cdot 107$ & 1500 & 0,40 & 0,05 \\
\hline 2. & Clay & $5,0 \cdot 106$ & 1600 & 0,45 & 0,05 \\
\hline 3. & $\begin{array}{l}\text { Sandy } \\
\text { loam }\end{array}$ & $8,0 \cdot 106$ & 1440 & 0,25 & 0,102 \\
\hline 4. & Loam & $1,3 \cdot 107$ & 1360 & 0,35 & 0,092 \\
\hline
\end{tabular}

Soil parameters for calculation is shown in the $1^{\text {st }}$ table. Vibration input $\mathrm{a}_{\mathrm{k}}=10 \mathrm{~mm} / \mathrm{s}^{2}, \mathrm{r}_{\mathrm{k}}=7,5 \mathrm{~m}$.

\section{Vibration map creation}

The numerical analysis was conducted using the equations shown before and represented as vibration maps. Every ground borne vibration map is $80 \times 50 \mathrm{~m}$ length and width and created using Surfer software. Grid is created using kriging method and contains 100x200 nodes. Principle scheme is shown in Fig. 3.

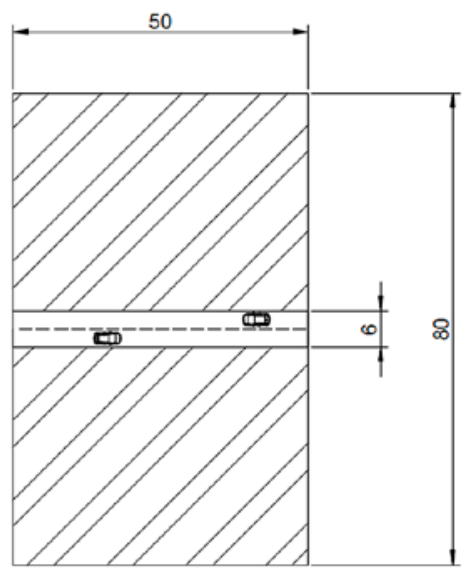

Fig. 3. Principle scheme of vibration model boundaries and modelled road

During calculations traffic flow is assumed as continuous and vehicle speed is constant. The width of the road is $6 \mathrm{~m}$.

\section{Results}

In this paper is four soil types are considered. In figure 4 is shown graph and map of vibration spread in the peat soil. In the graph is shown that maximum modelled vibration in the road section reach $18,6 \mathrm{~mm} / \mathrm{s}^{2}$. In $1 \mathrm{~m}$ distance to road, vibration decreases to $15 \mathrm{~mm} / \mathrm{s}^{2}$. In $40 \mathrm{~m}$ distance to the road acceleration decreases to $3 \mathrm{~mm} / \mathrm{s}^{2}$.

A)

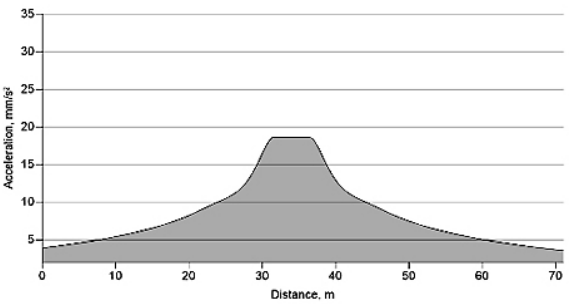

B)

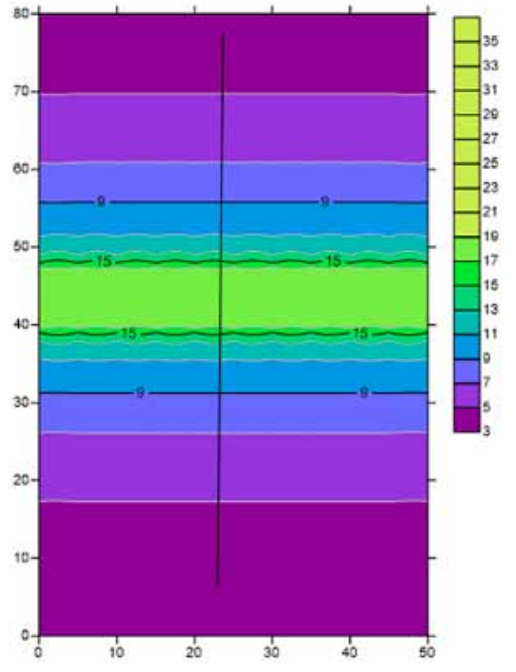

Fig. 4. Vibration spread in the peat soil A) Graph of vibration spread in distance, B) Vibration map in peat soil 
In figure 5 is shown graph and map of vibration spread in the clay soil. In the graph is shown that maximum modelled vibration in the road section reach $34,3 \mathrm{~mm} / \mathrm{s}^{2}$. In $1 \mathrm{~m}$ distance to road, vibration decreases to $20,8 \mathrm{~mm} / \mathrm{s}^{2}$. In $40 \mathrm{~m}$ distance to the road acceleration decreases to $0,3 \mathrm{~mm} / \mathrm{s}^{2}$. In clay soil the vibration near the source increases higher, but in long distance acceleration decreases more compared with peat soil.

A)

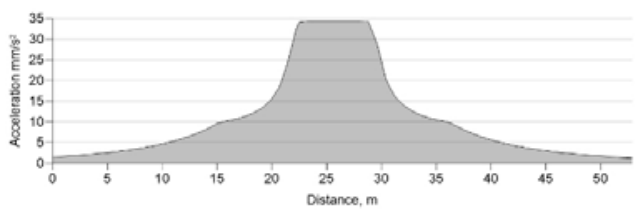

B)

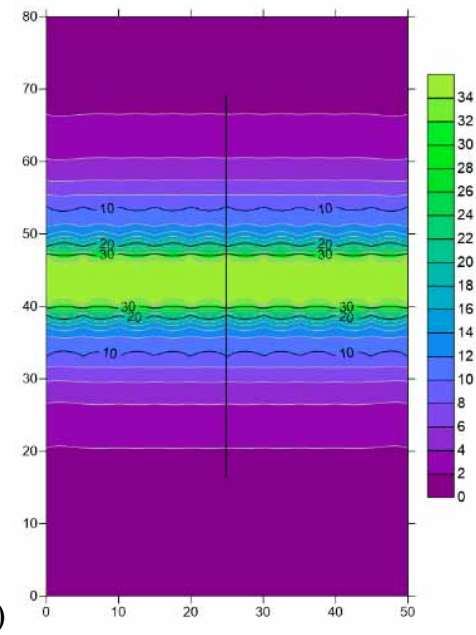

Fig. 5. Vibration spread in the clay soil. A) Graph of vibration spread in distance, B) Vibration map in clay soil

A)
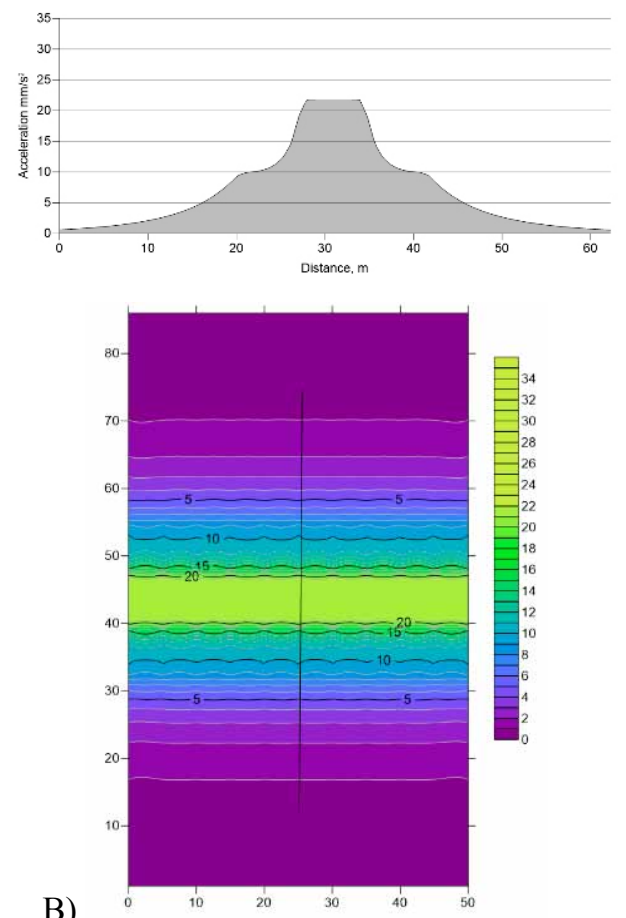

Fig. 6. Vibration spread in the sandy loam soil.

A) Graph of vibration spread in distance,

B) Vibration map in sandy loam soil
In figure 6 is shown graph and map of vibration spread in the sandy loam soil. In the graph is shown that maximum modelled vibration in the road section reach $21,8 \mathrm{~mm} / \mathrm{s}^{2}$. In $1 \mathrm{~m}$ distance to road, vibration decreases to $14,8 \mathrm{~mm} / \mathrm{s}^{2}$. In $40 \mathrm{~m}$ distance to the road acceleration decreases to $0,2 \mathrm{~mm} /$ $\mathrm{s}^{2}$. In sandy loam soil the vibration near the source is higher than in peat soil but lower than in the clay. In distance of $40 \mathrm{~m}$ to the road section modeled vibration acceleration was lower compared with both: peat and clay soils.

A)
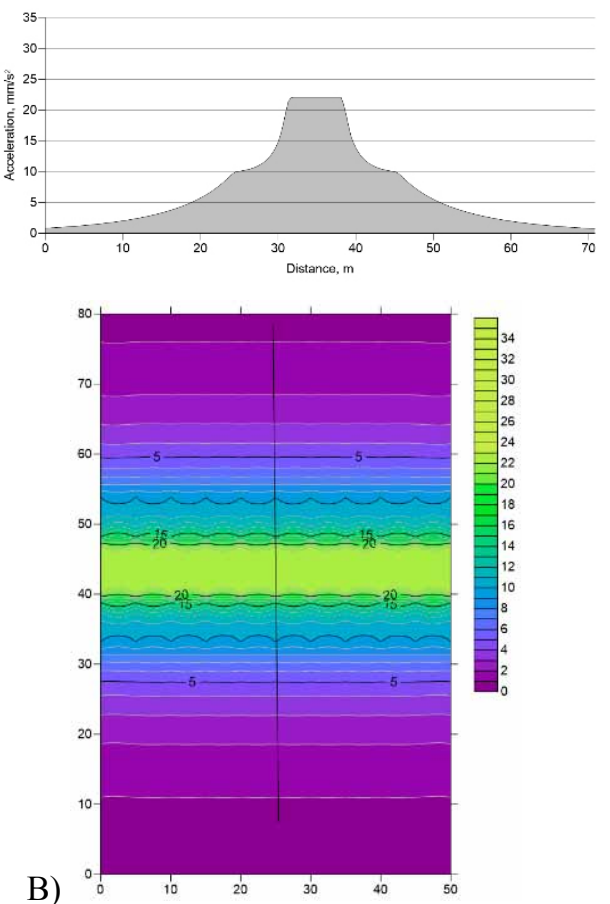

Fig. 7. Vibration spread in the loam soil. A) Graph of vibration spread in distance, B) Vibration map in loam soil

In figure 7 is shown graph and map of vibration spre$\mathrm{ad}$ in the loam soil. In the graph is shown that maximum modelled vibration in the road section reach $22,1 \mathrm{~mm} / \mathrm{s}^{2}$. In $1 \mathrm{~m}$ distance to road, vibration decreases to $15,5 \mathrm{~mm} / \mathrm{s}^{2}$. In $40 \mathrm{~m}$ distance to the road acceleration decreases to $0,4 \mathrm{~mm} / \mathrm{s}^{2}$. In loam soil the vibration near the source is lower than in clay soil but higher than in the peat and sandy loam soils. In distance of $40 \mathrm{~m}$ to the road section modeled vibration acceleration was lower compared with peat soil but higher compared with another two types of soil.

In the different types of soils the main parameters that influence vibration spread in soils is damping and density. If damping coefficient is low the vibrations gained from traffic is higher and spread distance is relatively longer.

In figure No. 8 is shown the comparison of transmission loss in different types of soil. Near the road significantly higher acceleration was calculated in the clay soil $\left(34,3 \mathrm{~mm} / \mathrm{s}^{2}\right)$. In two soils (sandy loam and loam) acceleration was similar in whole calculated area, the vibration acceleration near the source was $14,8 \mathrm{~mm} / \mathrm{s}^{2}$ and $15,5 \mathrm{~mm} / \mathrm{s}^{2}$ 


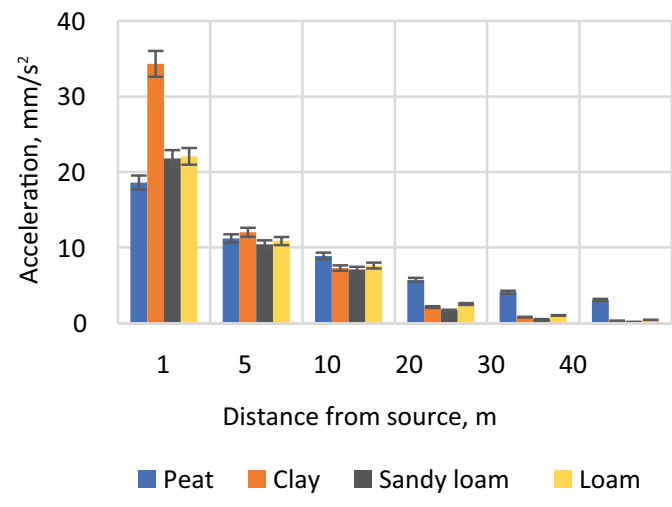

Fig. 8. Comparison of vibration spread in different types of soil

respectively, in the $40 \mathrm{~m}$ distance to the road modelled acceleration was $0,2 \mathrm{~mm} / \mathrm{s}^{2}$ and $0,4 \mathrm{~mm} / \mathrm{s}^{2}$. The vibrations calculated in the peat soil was lower near the vibration source $\left(18,6 \mathrm{~mm} / \mathrm{s}^{2}\right)$ but in $40 \mathrm{~m}$ distance from road acceleration calculated reached $3,0 \mathrm{~mm} / \mathrm{s}^{2}$. The most influencing parameter of soil properties is viscous damping constant (VDC) (Beards 1995). This parameter shows how much medium is able to vibrate. In peat and clay soils this parameter is low and in sandy loam and loam soils VDC is much higher.

These gained values could not be compared with other authors experimental results because source strength $a_{k}$ is used same in all types soil, and in natural conditions it would be different in different soils.

The gained results compared with other authors are similar, sandy and loam soils absorb vibration more, while in peat and clay soils this parameter is low and in sandy loam and loam soils VDC is much higher.

The gained results compared with oher authors are similar, sandy and loam soils absorb vibration more, while clay and peat soils less (Hajek et al. 2006; Harris Miller Miller, Hanson Inc. 1995; Kouroussis et al. 2012).

\section{Conclusions}

1. The highest transmission loss in soil was found in clay soil, the lowest in the peat. The difference is based on dynamic soil resistance. The phenomenon is based on physical and dynamic soil parameters. The most influencing factor is surface wave speed which is based on soil e-modulus, density and poisson ratio.

2. Highest ground-borne vibration near source was gained in clay soil $\left(34,3 \mathrm{~mm} / \mathrm{s}^{2}\right)$ and lowest in peat $\left(18,6 \mathrm{~mm} / \mathrm{s}^{2}\right)$.

3 . In the different types of loam traffic induced vibrations were similar (sandy loam $-22,1 \mathrm{~mm} / \mathrm{s}^{2}$, loam $22,1 \mathrm{~mm} / \mathrm{s}^{2}$ )

4. In the $40 \mathrm{~m}$ distance from road highest calculated vibration acceleration was in the peat $\left(3,0 \mathrm{~mm} / \mathrm{s}^{2}\right)$, and lowest in the sandy loam $\left(0,2 \mathrm{~mm} / \mathrm{s}^{2}\right)$

\section{References}

Athanasopoulos, G. A.; Pelekis, P. C., Anagnostopoulos, G. A. 2000. Effect of soil stiffness in the attenuation of Rayleigh-wave motions from field measurements, Soil Dynamics and Earthquake Engineering 19(4): 277-288. ISSN 0267-7261.

Banedanmark. 2015. New vibration model. Technical report. Kongens Lyngby, Denmark.

Beards, C. F. 1995. Engineering vibration analysis with applications to control systems. Study book. ISBN 034063183X.

Bolton, M. D.; Wilson, J. M. R. 1990. Soil stiffness and damping. Study book. Cambridge: Cambridge University. ISBN 9061911680.

Gibson, G. C.; Coyle, H. M. 1968. Soil damping constants rel ted to common soil properties in sands and clays. Research report No. 125-1. Texas transportation institute. College Station, Texas.

Hajek, J. J.; Blaney, C. T.; Hein, D. K. 2006. Mitigation of highway traffic-induced vibration, in 2006 Annual Conference of the Transportation Association of Canada. Charlottetown, Prince Edward Island.

Harris Miller Miller, Hanson Inc. 1995. Transit noise and vibration impact assessment. Manual.

Hunaidi, O. 2000. Traffic vibrations in buildings. Construction Technology Update No. 39.

Ingels, J. 2003. Landscaping principles and practices. 6th ed. Study book. Delmar Thomson Learning. ISBN 9781401834104.

Kaufmann, R. K.; Cutler, J. C. 2008. Environmental Science. Study book. McGraw-Hill Science/Engineering/Math. ISBN100073311863.

Kouroussis, G.; Conti, C.; Verlinder, O. 2012. Investigating the influence of soil properties on railway traffic vibration using a numerical model, International Journal of Vehicle Mechanics and Mobility 51(3): 421-442.

Kezdi, A. 1974. Handbook of soil mechanics. Elsevier, Amsterdam.

Mott, P. H.; Roland, C. M. 2012. Limits to Poisson's ratio in isotropic materials - general result for arbitrary deformation. Chemistry Division, Naval Research Laboratory, Code 6120, Washington DC 20375-5342.

Obrzud, R.; Truty, A. 2012. The hardening soil model - a practical guidebook. Z Soil.PC 100701 report.

\section{AUTOMOBILIU巳 TRANSPORTO SUKELIAMŲ ŽEMĖS VIBRACIJŲ MODELIAVIMAS}

\section{T. Astrauskas, R. Grubliauskas}

Santrauka

Automobilių sukeliamos žemės vibracijos yra dažna aplinkosauginė problema, su kuria susiduria gyventojai, turintys būstus netoli kelių, kuriuose automobilių srautas yra didelis. Kiekvienas kelio važiuojamosios dalies paviršiaus nelygumas didina automobilių sukeliamas žemès vibracijas. Vibracija sklinda per dirvožemi, kiekvienas dirvožemio tipas turi skirtingas fizines savybes, o tai reiškia skirtingą vibracijos bangu pralaidumą. Šiame straipsnyje yra nagrinejamas vibracijos sklidimas skirtinguose dirvožemiuose taikant skaitini modeliavima, o rezultatams atvaizduoti naudojama Surfer programinè įranga. Šiame straipsnyje tyrinejjami Lietuvoje dažnai pasitaikantys dirvožemio tipai: durpès, molis, priesmèlis ir priemolis. Skaičiavimai rodo, kad vibracija toliausiai sklinda durpèse, palyginti su kitais skaičiuotais dirvožemio tipais.

Reikšminiai žodžiai: transportas, žeme sklindančios vibracijos, skaitinis modeliavimas, vibracijos žemėlapis. 